\title{
Keefektifan Teknik Latihan Asertif terhadap Komunikasi Interpersonal dan Konformitas Teman Sebaya Siswa
}

\author{
(The Effect of Assertive Training on Student's Interpersonal Communication and Peer \\ Conformity)
}

\author{
Nur Yulianto Akbar*, Muhammad Nur Wangid, Galuh Prawitasari \\ Program Studi Bimbingan dan Konseling, Program Pascasarjana, Universitas Negeri Yogyakarta, \\ Jl. Colombo No.1, Sleman, Daerah Istimewa Yogyakarta, Indonesia 55281 \\ *corresponding author, e-mail: akbarzouleyw@gmail.com
}

Article received: September $4^{\text {th }} 2019$; revised: October $25^{\text {th }} 2019$; accepted: October $2^{\text {th }} 2019$

\begin{abstract}
Both interpersonal communication and conformity are prominent variables for adolescent's social development. Adolescent who fails to establish a good interpersonal communication may turn to an aggressive individual, while the one who is too conformist will be more vulnerable to engage in juvenile delinquency. This study aims to investigate the effect of assertive training on interpersonal communication and peer conformity of junior high school students. 12 eighth graders of Junior High School Muhammadiyah 2 Mlati Yogyakarta were involved in the study. The study applied a Quasi Experimental approach with non-equivalent-groups pretest-posttest design. To gather research data, the study used Interpersonal Communication and Peer Conformity Scales. The result shows that assertive training is effective to increase interpersonal communication and to decrease the level of peer conformity. Based on the result, the next study needs to compare the effect of assertive training and other behavioral techniques on the two variables.
\end{abstract}

Keywords: assertive training; interpersonal communication; peer conformity; behavioral

\begin{abstract}
Abstrak: Komunikasi interpersonal maupun konformitas merupakan dua variabel penting dalam perkembangan kehidupan sosial remaja. Remaja yang gagal membangun komunikasi interpersonal dengan baik dapat menjadi remaja agresif, sedangkan remaja yang terlampau konformis rentan terlibat dalam kenakalan remaja. Penelitian ini bertujuan mengetahui keefektifan teknik asertif terhadap komunikasi interpersonal dan tingkat konformitas teman sebaya pada siswa sekolah menengah pertama (SMP). Subjek penelitian adalah 12 siswa kelas delapan SMP Muhammadiyah 2 Mlati, Yogyakarta. Penelitian ini merupakan penelitian Quasi Eksperimen menggunakan desain pretest dan posttest. Instrumen yang digunakan adalah skala komunikasi interpersonal dan skala konformitas teman sebaya. Hasil penelitian menunjukkan bahwa teknik latihan asertif efektif untuk meningkatkan komunikasi interpersonal dan menurunkan tingkat konformitas teman sebaya subjek. Penelitian selanjutnya dapat membandingkan keefektifan teknik asertif dengan teknik behavioral lainnya.
\end{abstract}

Kata kunci: latihan asertif; komunikasi interpersonal; konformitas teman sebaya; behavioral 


\section{PENDAHULUAN}

Keterampilan komunikasi interpersonal merupakan modal yang penting untuk dapat menjalankan interaksi sosial yang baik (Erozkan, 2013). Komunikasi interpersonal adalah komunikasi yang terjadi antara interaksi verbal dan nonverbal antara dua (atau kadang-kadang lebih dari dua) orang yang saling tergantung satu sama lain, sehingga dalam berkomunikasi saling terhubung antara satu dengan yang lainnya untuk mencapai kesamaan makna dalam berkomunikasi (DeVito, 2012). Individu pemilik kemampuan komunikasi interpersonal yang baik akan dapat membina hubungan baik dengan individu lainnya, sehingga menghindari dan mampu mengatasi terjadinya konflik-konflik di antara individuindividu tersebut.

Hasil observasi prasurvei terhadap seluruh siswa kelas VIII di SMP Muhammadiyah 2 Mlati yang berjumlah 108 siswa dengan menggunakan daftar cek masalah menunjukkan adanya masalah bidang hubungan sosial yang berkaitan dengan komunikasi interpersonal. Sebanyak $77 \%$ siswa mengalami kesulitan untuk mengungkapkan masalah dan 67\% siswa kesulitan dalam berkomunikasi dalam lingkungan sekolah yang memengaruhi proses interaksi siswa dengan teman dan gurunya. Selain masalah komunikasi interpersonal, 59\% siswa terpengaruh oleh pendapat teman-temannya dalam mengambil keputusan dan $66 \%$ siswa kesulitan untuk menyesuaikan diri dengan kebiasaaan teman-teman dalam kelompok, hal ini berarti terdapat permasalahan dalam bidang hubungan sosial yang berkaitan dengan konformitas.

Sikap konformis dapat memberikan dampak yang positif maupun negatif bagi diri remaja (Collier, Bos, \& Sandfort, 2012; Mahrunnisya, Indriayu, \& Wardani, 2018; Teunissen et al., 2012) bergantung dengan siapa dan di mana remaja tersebut berada. Apabila remaja berada pada lingkungan dengan kondisi baik, seperti lingkungan agamis, penuh kedisplinan, penuh ketertiban, maka remaja akan mengikuti dan menyesuaikan dengan lingkungan yang baik tersebut. Sebaliknya, apabila remaja berada di lingkungan pergaulan yang negatif, seperti merokok, kenakalan, geng, urakan, dan membolos sekolah, maka ia akan memperoleh tekanan yang pada akhirnya terpengaruh dan mengikuti aktivitas negatif kelompok tersebut.

Sebuah hasil penelitian menunjukkan bahwa konformitas teman sebaya berhubungan positif dengan kenakalan remaja (Hidayati, 2016). Artinya, semakin tinggi konformitas teman sebaya, maka potensi kenakalan remaja juga akan semakin tinggi. Guna mereduksi perilaku konformis yang bersifat negatif, siswa dapat diberikan latihan asertif (Prastiwi, 2014). Teknik latihan asertif berlandaskan pada pendekatan behaviorisme dengan asumsi dasar bahwa setiap orang memiliki hak untuk mengungkapkan perasaannya, pendapat, apa yang diyakini serta sikap untuk melaksanakan suatu hal tanpa ragu namun tanpa menyakiti perasaan orang lain (Corey, 2013). Teknik asertif dipandang tepat untuk membantu klien/konseli yang tidak dapat menyatakan kemarahan atau kejengkelannya, yang bersikap sopan secara berlebihan dan membiarkan orang lain mengambil keuntungan darinya, yang mengalami kesulitan untuk berkata "tidak", serta yang seringkali merasakan tidak punya hak untuk menyatakan pendapat dan pikirannya. Hasil penelitian sebelumnya membuktikan bahwa latihan asertif dapat meningkatkan kepercayaan diri mahasiswa, mengurangi kecemasan interaksi sosial pada individu yang mengalami skizofrenia, dan meningkatkan keterampilan sosial siswa (Hasanah, Supriyono, Herani, \& Lestari, 2010; Mohamed \& Abd El Aziz, 2016).

Teknik asertif dalam penelitian ini akan diberikan melalui layanan konseling kelompok dengan pertimbangan layanan ini belum pernah diterapkan di sekolah yang menjadi subjek penelitian. Selain itu, konseling kelompok dapat memberi anggota kelompok kesempatan untuk saling berinteraksi dan lebih mengetahui seseorang (Defriyanto \& Masitoh, 2016). Di dalam kelompok siswa dapat saling membantu pernyataan, masukan, gagasan dan hasil nilai pada anggota kelompok yang lain. Dengan kata lain layanan konseling kelompok membantu siswa untuk belajar secara aktif (Jacobs, Masson, Harvill, \& Schimmel, 2011).

Penelitian ini bertujuan untuk menguji keefektifan teknik asertif untuk meningkatkan keterampilan komunikasi interpersonal dan menurunkan tingkat konformitas terhadap teman sebaya pada siswa SMP. Dengan meningkatnya komunikasi interpersonal serta menurunnya konformitas terhadap teman sebaya, diharapkan siswa mampu menyatakan pendapat dan pikirannya sendiri secara baik tanpa menyakiti siapapun serta mampu bersikap dan berperilaku sesuai dengan yang diyakininya tanpa bertentangan dengan norma-norma yang berlaku. 


\section{METODE}

Penelitian ini merupakan penelitian kuantitatif dengan rancangan eksperimen dan menggunakan Non-equivalent-Groups Pretest-Posttest Design. Pada tahap awal sebanyak 112 siswa kelas delapan SMP Muhammadiyah 2 Mlati Yogyakarta tahun ajaran 2018- 2019 mengisi dua jenis skala, yaitu Skala Komunikasi Interpersonal $(\alpha=0,921)$ dan Skala Konformitas terhadap Teman Sebaya $(\alpha=0,930)$, yang masing-masing terdiri atas 23 butir.

Hasil pelancaran kedua skala tersebut menunjukkan dua belas siswa memiliki tingkat komunikasi interpersonal yang relatif lebih rendah serta tingkat konformitas yang relatif lebih tinggi dibanding 110 siswa lainnya. Selanjutnya, dua belas siswa tersebut dibagi dalam dua kelompok secara acak sehingga terbentuklah kelompok eksperimen dan kelompok kontrol yang masing-masing terdiri atas enam siswa. Kelompok eksperimen adalah kelompok siswa yang diberikan perlakuan layanan konseling kelompok dengan teknik latihan asertif, sedangkan kelompok kontrol memperoleh perlakuan berupa teknik diskusi.

Layanan konseling kelompok dengan teknik latihan asertif diberikan selama delapan sesi dan meliputi tiga tahapan, yaitu tahap awal, tahap kerja, dan tahap akhir. Tahap awal menekankan pada building rapport antara peneliti/konselor dengan konseli/siswa dalam kelompok eksperimen yang meliputi: perkenalan diri, penjelasan tujuan pelaksanaan konseling, eksplorasi tentang harapan serta kekhawatiran terhadap proses konseling yang akan dilakukan. Pada tahap kerja, tiap konseli diberikan kesempatan untuk melakukan enam sub tahapan yang terdiri atas: (1) mengidentifikasi keadaan yang menimbulkan persoalan bagi konseli; (2) peneliti, anggota kelompok, dan konseli membedakan perilaku asertif dan tidak asertif serta menentukan perubahan perilaku yang diharapkan; (3) bermain peran, pemberian umpan balik, serta pemberian model perilaku yang lebih baik; (4) melaksanakan latihan dan mempraktikkan perilaku seperti saran dan umpan balik yang diberikan peneliti dan anggota kelompok yang lain; (5) konseli mengulang latihan kembali tanpa bantuan peneliti dan anggota kelompok yang lain; (6) peneliti memberi tugas rumah kepada konseli untuk mempraktikkan perilaku yang sudah diperankan dalam kehidupan sehari-hari.

Pada tahap akhir, peneliti dan anggota kelompok mendiskusikan hasil dan perlakuan berupa teknik latihan asertif yang sudah dilakukan. Peneliti dan anggota kelompok menyampaikan perasaan yang dimiliki selama proses konseling kelompok dan masing-masing anggota kelompok menceritakan pengalaman mereka dalam mengatasi masalahnya serta menceritakan kegagalan maupun keberhasilan mereka ketika melakukan perubahan. Terakhir, peneliti dan anggota kelompok melakukan evaluasi terhadap pelaksanaan layanan konseling kelompok dengan teknik latihan asertif.

Setelah proses pemberian perlakuan berakhir, tingkat komunikasi interpersonal dan konformitas kedua kelompok diukur kembali menggunakan skala yang sama diberikan pengukuran akhir (posttest) dengan menggunakan Skala Komunikasi Interpersonal dan Skala Konformitas. Pengujian hipotesis dilakukan dengan menggunakan uji statistik non parametris Wilcoxon dan Mann Whitney (U), hal ini dikarenakan jumlah sampel dalam penelitian tidak lebih dari 30 sampel.

\section{HASIL}

Perbandingan hasil pretest dan posttest kelompok eksperimen dan kelompok kontrol untuk variabel komunikasi interpersonal dan konformitas melalui uji statistik deskriptif disajikan pada tabel 1. Pada tabel 1 nilai rata-rata kelompok eksperimen untuk variabel komunikasi interpersonal sesudah perlakuan adalah 73,33 atau meningkat 26,33 poin dibanding mean skor pretest. Adapun nilai rata-rata kelompok eksperimen untuk variabel konformitas setelah perlakuan adalah 42,33 atau menurun 33,34 poin dari mean skor pretest.

Berbeda dengan kelompok eksperimen, skor rerata kelompok kontrol untuk variabel komunikasi interpersonal maupun variabel konformitas relatif tidak berubah. Data pada tabel 2 , terlihat bahwa mean untuk variabel komunikasi interpersonal sesudah perlakuan adalah 47,67 atau hanya meningkat 2,5 poin dibanding mean skor pretest. Adapun nilai rata-rata kelompok kontrol untuk variabel konformitas setelah perlakuan adalah 72,17 atau hanya berubah 0,34 poin dari mean skor pretest.

Tahap selanjutnya adalah uji hipotesis dengan menggunakan Mann Whitney Test dan Wilcoxon Signed Ranks Test. Uji Mann-Whitney bertujuan untuk mengetahui perbedaan mean antara kelompok eksperimen dan kelompok kontrol pada saat pretest dan posttest, sedangkan Wilcoxon Signed Ranks Test digunakan untuk melihat perbedaan mean antara skor pretest dan posttest pada masing-masing 
Tabel 1. Hasil Uji Statistik Deskriptif Data Pretest dan Posttest Kelompok Eksperimen

\begin{tabular}{lccc}
\hline Data & N & Mean Skor Komunikasi Interpersonal & Mean Skor Konformitas \\
\hline Pretest & 6 & 47 & 75,67 \\
Posttest & 6 & 73,33 & 42,33 \\
\hline
\end{tabular}

Tabel 2. Hasil Uji Statistik Deskriptif Data Pretest dan Posttest Kelompok Kontrol

\begin{tabular}{lccc}
\hline Data & N & Mean Skor Komunikasi Interpersonal & Mean Skor Konformitas \\
\hline Pretest & 6 & 45,17 & 71,83 \\
Posttest & 6 & 47,67 & 72,17 \\
\hline
\end{tabular}

kelompok eksperimen maupun kelompok kontrol setelah perlakuan diberikan. Pada uji Mann Whitney maupun uji Wilcoxon, jika nilai sig. atau p value $<$ batas kritis 0,05 artinya terdapat perbedaan bermakna antara dua kelompok. Sebaliknya, jika $\mathrm{p}$ value $>0,05$ artinya tidak terdapat perbedaan mean antara dua kelompok yang diteliti.

Uji Mann-Whitney data pretest komunikasi interpersonal dan konformitas pada kelompok eksperimen maupun kelompok kontrol menunjukkan $\mathrm{p}$ value berturut-turut 0,808 dan 0,336 atau lebih besar dari 0,05. Artinya, kedua kelompok tersebut tidak memiliki perbedaan tingkat komunikasi interpersonal dan konformitas sebelum perlakuan diberikan. Adapun uji Mann-Whitney terhadap data posttest komunikasi interpersonal dan konformitas pada kelompok eksperimen dan kelompok kontrol menunjukkan $\mathrm{p}$ value masing-masing 0,004 atau lebih kecil dari 0,05. Artinya, terdapat perbedaan bermakna pada skor komunikasi interpersonal dan skor konformitas antara kelompok eksperimen dan kelompok kontrol setelah diberikan perlakuan.

Uji Wilcoxon terhadap variabel komunikasi interpersonal dan konformitas pada kelompok eksperimen menunjukkan $\mathrm{p}$ value masing-masing sebesar 0,027 dan 0,028 . Kedua $\mathrm{p}$ value tersebut lebih kecil dari 0,05 sehingga terdapat perbedaan tingkat komunikasi interpersonal dan konformitas pada kelompok eksperimen sebelum dan setelah diberikan perlakuan teknik asertif. Adapun $\mathrm{p}$ value dari uji Wilcoxon terhadap variabel komunikasi interpersonal dan konformitas untuk kelompok kontrol berturut-turut sebesar 0,248 dan 0,596. Oleh karena kedua $\mathrm{p}$ value lebih besar dari 0,05 , maka tidak terdapat perbedaan tingkat komunikasi interpersonal dan konformitas pada kelompok kontrol.

\section{PEMBAHASAN}

Penelitian ini bertujuan untuk mengetahui keefektifan teknik latihan asertif untuk meningkatkan komunikasi interpersonal dan menurunkan tingkat konformitas teman sebaya pada siswa SMP. Perlakuan berupa teknik latihan asertif diberikan kepada enam siswa dalam kelompok eksperimen, sedangkan enam siswa lainnya yang berada pada kelompok kontrol menerima perlakuan berupa teknik diskusi. Melalui uji Wilcoxon, hipotesis penelitian bahwa teknik latihan asertif dapat meningkatkan komunikasi interpersonal terbukti karena terdapat perbedaan tingkat komunikasi interpersonal pada kelompok eksperimen sebelum dan setelah pemberian perlakuan.

Teknik latihan asertif efektif untuk meningkatkan komunikasi interpersonal sebab di dalam teknik latihan asertif individu dibimbing untuk mampu menyampaikan apa yang menjadi pendapat atau kebutuhan dirinya kepada orang lain, sehingga tercipta hubungan sosial yang baik antara subjek dengan individu lainnya dalam kelompok (Braz, Del Prette, \& Del Prette, 2011; Sommerfeld et al., 2019). Komunikasi interpersonal yang berhubungan erat dengan kepercayaan diri (Utomo \& Harmiyanto, 2016), akan berdampak pada sosialisasi individu dengan orang lain. Pengaruh kekerabatan dari daya komunikasi interpersonal individu pada akhirnya akan berdampak pula pada hasil kinerjanya dalam melaksanakan suatu hal. Sebagaimana diketahui bahwa keberhasilan individu bergantung pada caranya dalam mengorganisir kemampuan yang dimiliki, salah satunya kemampuan komunikasi interpersonal yang baik (Drussell, 2012). Peningkatan aspek komunikasi interpersonal untuk siswa merupakan hal yang penting, sebab komunikasi interpersonal sangat berpengaruh pada prokrastinasi akademik siswa (Putri \& Sawitri, 2018). Dengan memiliki komunikasi interpersonal yang baik, individu dapat terhindar dari konflik interpersonal karena konflik dapat terjadi akibat komunikasi yang tidak efektif (Babatunde, 2015). 
Selain meningkatkan komunikasi interpersonal siswa, penelitian ini juga membuktikan keefektifan teknik latihan asertif untuk mengurangi konformitas siswa terhadap teman sebaya. Hasil uji Wilcoxon menunjukkan $\mathrm{p}$ value data konformitas kelompok siswa yang memperoleh perlakuan teknik latihan asertif sebesar 0,028 atau lebih kecil dari 0,05, sehingga terdapat perbedaan tingkat konformitas pada kelompok eksperimen pada sebelum dan setelah diberi perlakuan teknik latihan asertif.

Teknik latihan asertif efektif untuk mengurangi konformitas sebab di dalam teknik asertif siswa dibimbing untuk melatih bagaimana cara menegaskan diri secara langsung serta mengetahui bahwa setiap orang mempunyai hak untuk mengutarakan perasaan, ajaran, keyakinan, dan perilaku mereka tanpa keraguan dan dengan cara yang baik (Ituga, 2017). Siswa yang mampu bersikap asertif akan terhindar dari perilaku agresif, sebab sebuah penelitian menunjukkan semakin tinggi tingkat konformitas maka semakin besar kesempatan siswa untuk bersikap agresif (Zollman, 2010). Selaras hasil penelitian tersebut, penelitian lain juga menunjukkan bahwa konformitas terhadap kelompok sebaya adalah faktor penting dalam dampak sikap agresif di kalangan siswa (Imtiaz, Yasin, \& Yaseen, 2010).

Selain keagresifan, konformitas terhadap teman sebaya juga terbukti berkaitan dengan kenakalan siswa (Asih, Winarno, \& Hastuti, 2012). Siswa yang memiliki tingkat konformitas tinggi akan lebih banyak tergantung pada aturan dan norma yang berlaku dalam kelompoknya, sehingga identitas diri (self-identity) siswa berkurang, hal ini dikarenakan konformitas memiliki hubungan yang negatif dengan identitas diri (Ana, Febriana, \& Mayangsari, 2016; Ramadhana, Karsidi, Utari, \& Kartono, 2019). Siswa yang terlalu konformis akan membaktikan dirinya pada kelompok dan kadang-kadang kebahagiaan baru dirasakan saat perilakunya sama dengan perilaku anggota kelompok lainnya. Kondisi ini dapat menyebabkan perilaku siswa terlalu condong pada aktivitas kelompok dan bukan berasal dari dirinya sendiri.

\section{SIMPULAN}

Penggunaan teknik latihan asertif efektif untuk meningkatkan komunikasi interpersonal dan menurunkan tingkat konformitas teman sebaya siswa SMP. Temuan ini dapat dijadikan alternatif strategi intervensi oleh konselor sekolah untuk membantu mengatasi permasalahan konseli dalam bidang layanan sosial, khususnya dalam rangka mengembangkan keterampilan hubungan sosial yang efektif dan mencegah kenakalan remaja. Penerapan teknik latihan asertif dapat menunjang pencapaian tugas perkembangan siswa SMP, di antaranya mencapai pola hubungan yang baik dengan teman sebaya serta mencapai kematangan hubungan dengan teman sebaya. Peneliti selanjutnya diharapkan dapat membandingkan teknik asertif dengan teknik behavioral lainnya untuk mengetahui tingkat keefektifan teknik lain tersebut terhadap variabel komunikasi interpersonal dan konformitas terhadap teman sebaya.

\section{DAFTAR RUJUKAN}

Ana, N., Febriana, S. K. T., \& Mayangsari, M. D. (2016). Hubungan identitas diri dengan konformitas pada mahasiswa yang mengikuti Hizbut Tahrir. Jurnal Ecopsy, 2(2).

Asih, M. K., Winarno, R. D., \& Hastuti, L. W. (2012). Hubungan konformitas teman sebaya dan keharmonisan keluarga dengan kenakalan remaja pada anak didik Lembaga Pemasyarakatan Anak Kutoarjo. PREDIKSI, 1(2), 189-193.

Babatunde, O. (2015). Importance of effective communication in public organisations. Issues in Social Science, $3(2), 78-89$.

Braz, A. C., Del Prette, Z. A. P., \& Del Prette, A. (2011). Assertive social skills training for the elderly. Behavioral Psychology/ Psicologia Conductual.

Collier, K. L., Bos, H. M. W., \& Sandfort, T. G. M. (2012). Intergroup contact, attitudes toward homosexuality, and the role of acceptance of gender non-conformity in young adolescents. Journal of Adolescence, 35(4), 899-907.

Corey, G. (2013). Theory and practice of counseling and psychotherapy (Ninth). Brooks/Cole.

Defriyanto, D., \& Masitoh, S. (2016). Pengaruh assertiveness training terhadap konsep diri pada peserta didik kelas X di SMK N 5 Bandar Lampung tahun pelajaran 2015/2016. KONSELI: Jurnal Bimbingan dan Konseling (E-Journal), 3(1), 83-96.

DeVito, J. A. (2012). The interpersonal communication book. Pearson. 
Drussell, J. (2012). Social networking and interpersonal communication and conflict resolution skills among college freshmen.

Erozkan, A. (2013). The effect of communication skills and interpersonal problem solving skills on social selfefficacy. Educational Sciences: Theory and Practice, 13(2), 739-745.

Hasanah, N., Supriyono, Y., Herani, I., \& Lestari, S. (2010). Peningkatan kepercayaan diri mahasiswa melalui pelatihan asertivitas. Interaktif, 1(2).

Hidayati, N. W. (2016). Hubungan harga diri dan konformitas teman sebaya dengan kenakalan remaja. Jurnal Penelitian Pendidikan Indonesia, 1(2), 31-36.

Imtiaz, R., Yasin, G., \& Yaseen, A. (2010). Sociological study of the factors affecting the aggressive behavior among youth. Pakistan Journal of Social Sciences (PJSS), 30(1).

Ituga, A. S. (2017). Efektivitas teknik latihan asertif untuk meningkatkan internal locus of control siswa dalam belajar. Jurnal Psikologi Pendidikan dan Konseling: Jurnal Kajian Psikologi Pendidikan dan Bimbingan Konseling, 8-14.

Jacobs, E. E., Masson, R. L. L., Harvill, R. L., \& Schimmel, C. J. (2011). Group counseling: Strategies and skills. Cengage learning.

Mahrunnisya, D., Indriayu, M., \& Wardani, D. K. (2018). Peer conformity through money attitudes toward adolescence's consumptive behavior. International Journal of Multicultural and Multireligious Understanding, $5(4), 30-37$.

Mohamed, S. M., \& Abd El Aziz, E. M. (2016). Effect of assertive training program on social interaction anxiety and self-esteem of institutionalized patients with chronic schizophrenia. IOSR J Nurs Health Sci, 5(5), 36-44.

Prastiwi, A. (2014). Penerapan strategi assertive training untuk mereduksi perilaku konformitas pada teman sebaya kelas XI IPS 4 SMAN 3 Lamongan. Jurnal BK UNESA, 4(3).

Putri, S. A., \& Sawitri, D. R. (2018). Hubungan antara hardiness dengan stres akademik pada taruna tingkat II politeknik ilmu pelayaran Semarang. Empati, 6(4), 319-322.

Ramadhana, M. R., Karsidi, R., Utari, P., \& Kartono, D. T. (2019). Role of family communications in adolescent personal and social identity. Journal of Family Sciences, 4(1), 1-11. https://doi.org/10.29244/jfs.4.1.1-11

Sommerfeld, D. H., Aarons, G. A., Naqvi, J. B., Holden, J., Perivoliotis, D., Mueser, K. T., \& Granholm, E. (2019). Stakeholder perspectives on implementing cognitive behavioral social skills training on assertive community treatment teams. Administration and Policy in Mental Health and Mental Health Services Research, 46(2), $188-199$.

Teunissen, H. A., Spijkerman, R., Prinstein, M. J., Cohen, G. L., Engels, R. C. M. E., \& Scholte, R. H. J. (2012). Adolescents' conformity to their peers' pro-alcohol and anti-alcohol norms: The power of popularity. Alcoholism: Clinical and Experimental Research, 36(7), 1257-1267. https://oi.org/10.1111/j.15300277.2011.01728.x

Utomo, D., \& Harmiyanto, H. (2016). Hubungan keterampilan komunikasi interpersonal dan kepercayaan diri siswa kelas X Sman 1 Garum Kabupaten Blitar. Jurnal Kajian Bimbingan dan Konseling, 1(2), 55-59. https:// doi.org/10.17977/um001v1i22016p055

Zollman, K. J. S. (2010). Social structure and the effects of conformity. Synthese, 172(3), 317-340. 